\title{
REVIEWERS OF 2014
}

$\begin{array}{lll}\text { Nguyễn Đông Anh } & \text { Nguyễn Đức Hùng } & \text { Janos Somlo } \\ \text { Hồ Phạm Huy Ánh } & \text { Nguyễn Việt Hùng } & \text { Lê Hải Sơn } \\ \text { Đoàn Văn Ban } & \text { Trần Thanh Hùng } & \text { Trần Thái Sơn } \\ \text { Hồ Tú Bảo } & \text { Phan Trung Huy } & \text { Nguyễn Văn Tam } \\ \text { Tamás Bérczes } & \text { Huỳnh Hữu Hưng } & \text { Ngô Quốc Tạo } \\ \text { Vũ Đình Bảy } & \text { Đặng Trấn Khánh } & \text { Lê Hoàng Thái } \\ \text { Phạm Thượng Cát } & \text { Nguyễn Phi Khứ } & \text { Nguyễn Phương Thái } \\ \text { Lê Anh Cường } & \text { Trần Văn Lăng } & \text { Nguyễn Ngọc Thành } \\ \text { Bùi Thế Duy } & \text { Vũ Như Lân } & \text { Phạm Tuấn Thành } \\ \text { Nguyễn Đức Dũng } & \text { Hà Thành Lê } & \text { Trịnh Đình Thắng } \\ \text { Nguyễn Tuấn Đang } & \text { Trần Hoài Linh } & \text { Vũ Đức Thi } \\ \text { Đinh Điền } & \text { Nguyễn Thị Thúy Loan } & \text { Nguyễn Đình Thuân } \\ \text { Nguyễn Công Định } & \text { Ngô Thành Long } & \text { Nguyễn Thanh Thủy } \\ \text { Dương Anh Đức } & \text { Lương Chi Mai } & \text { Trần Ngọc Thúy } \\ \text { Đặng Văn Đức } & \text { Lê Quang Minh } & \text { Hà Quang Thụy } \\ \text { Nguyễn Huy Đức } & \text { Tạ Cao Minh } & \text { Đỗ Văn Tiến } \\ \text { Nguyễn Long Giang } & \text { Đỗ Hoài Nam } & \text { Nguyễn Tân Tiến } \\ \text { Phạm Thanh Giang } & \text { Phùng Trung Nghĩa } & \text { Đào Thanh Tĩnh } \\ \text { Lê Thanh Hà } & \text { Lý Quốc Ngọc } & \text { Đỗ Năng Toàn } \\ \text { Lê Vũ Hà } & \text { Nguyễn Chí Ngôn } & \text { Lê Ngọc Tú } \\ \text { Nguyễn Việt Hà } & \text { Nguyễn Doãn Phước } & \text { Phan Thị Tươi } \\ \text { Phạm Thanh Hà } & \text { Từ Minh Phương } & \text { Đào Hoa Việt } \\ \text { Nguyễn Ngọc Hóa } & \text { Nguyễn Phùng Quang } & \text { Yeon-Mo Yang } \\ \text { Nguyễn Quang Hoan } & \text { Vũ Hải Quân } & \text { Wunsch, Donald C } \\ \text { Thân Ngọc Hoàn } & \text { Lê Hoài Quốc } & \\ \text { Bùi Thê̂Hồng } & \text { Nguyễn Hữu Quỳnh } & \end{array}$


